\title{
VIPD Regimen
}

National Cancer Institute

\section{Source}

National Cancer Institute. VIPD Regimen. NCI Thesaurus. Code C140114.

A regimen consisting of etoposide, ifosfamide, cisplatin and dexamethasone that can be used in the treatment of natural killer (NK)/T-cell lymphoma. 